\title{
KAJIAN HUKUM ISLAM TERHADAP MANFAAT ZAKAT DALAM PENGEMBANGAN EKONOMI MASYARAKAT
}

\author{
Anwar Sadat Harahap ${ }^{1)}$, Dalyanto ${ }^{2)}$ \\ Universitas Muslim Nusantara (UMN) Al Washliyah ${ }^{1)}$ \\ Universitas Muslim Nusantara (UMN) Al Washliyah²)
}

\begin{abstract}
ABSTRAK
Zakat yang dikeluarkan itu merupakan milik orang lain yang berhak menerimanya. Pemelik harta hanya merupakan jembatan, perantaraan dan tempat penitipan sementara saja. Allah akan mengujinya, apakah ia rela memberikan hak orang lain dengan ikhlas atau tidak. Sesungguhnya zakat merupakan bagian dari sedekah yang wajib dikeluarkan oleh seseorang jika jumlah hartanya telah mencapai satu nishab (nilai harganya mencapai 94 gram emas) dan umur hartanya mencapai satu tahun. Kalu kedua syarat tersebut belum tercapai, maka kewajiban berzakat bagi seseorang tidak ada. Dengan begitu, yang diwajibkan berzakat adalah orang kaya yang telah memiliki harta melebihi kebutuhan pokoknya. Perlu diketahui bahwa segala kewajiban yang diberikan Allah kepada hambaNya pasti membawa kebaikan dan manfaat bagi manusia baik di dunia maupun di akhirat. Demikian halnya dengan pelaksanaan zakat, bila dilaksanakan secara ikhlas akan membawa manfaat bagi manusia terutama sekali dalam bidang peningkatan perekonomian masyarakat, antara lain : Zakat bermanfaat mengembangkan harta benda dalam masyarakat. Zakat bermanfaat menumbuhkan sifat kasih sayang terhadap sesama manusia. Zakat bermanfaat menghilangkan rasa dengki antara si miskin dengan si kaya. Ibadah zakat ini ternyata dapat menumbuhkan sifat ikhlas bagi pelakunya. Pelaksanaan ibadah zakat bermanfaat dalam menciptakan ketenangan dan ketentraman hidup dalam masyarakat. Kewajiban menunaikan zakat hanya dibebankan kepada orang yang memiliki kemampuan saja.
\end{abstract}

Kata Kunci: $\quad$ Hukum Islam, Zakat, Ekonomi, Masyarakat

\begin{abstract}
Zakat issued is the property of others who are entitled to receive it. The property owner is only a bridge, intermediary, and temporary storage. God will test it, whether he is willing to give the rights of others with sincerity or not. Indeed zakat is a part of alms that must be issued by someone if the amount of his wealth has reached one mishap (the value of the price reaches 94 grams of gold) and the life of the treasure reaches one year. If both of these conditions have not been met, then the obligation of tithing for someone does not exist. That way, those who are obliged to pay tithe are rich people who have more than their basic needs. Keep in mind that all obligations given by God to His servants must bring good and benefit to humans both in this world and the hereafter. Likewise with the implementation of zakat, if it is carried out sincerely it will bring benefits to humans, especially in the field of improving the economy of the community, including Zakat is useful in developing property in society. Zakat is beneficial to foster compassion towards fellow human beings. Zakat is useful to eliminate the envy between the poor with the rich. It turns out that zakat worship can foster a sincere nature for the culprit. The implementation of zakat worship is beneficial in creating calm and peace of life in society. Obligation to pay zakat is only borne by people who have the ability.
\end{abstract}

Keywords: Islamic Law, Zakat, Economy, Society

\section{PENDAHULUAN}

Tidak dapat disangkal bahwa masih ada sebagian orang yang enggan mengeluarkan zakat hartanya, walaupun hanya diwajibkan sekali dalam setahun bagi mereka yang memiliki kemampuan. Perasaan berat hati itu muncul disebabkan oleh ketidak pahaman mereka secara mendalam tentang manfaat yang diperoleh di balik pelaksanaan zakat itu sendiri. Andai saja mereka paham, tentu muncul rasa kesungguhan dan keikhlasan dalam menunaikannya. 
Sesungguhnya zakat merupakan bagian dari sedekah yang wajib dikeluarkan oleh seseorang jika jumlah hartanya telah mencapai satu nishab (nilai harganya mencapai 94 gram emas) dan umur hartanya mencapai satu tahun. Kalu kedua syarat tersebut belum tercapai, maka kewajiban berzakat bagi seseorang tidak ada. Dengan begitu, yang diwajibkan berzakat adalah orang kaya yang telah memiliki harta melebihi kebutuhan pokoknya.

Perlu disadari bahwa zakat yang dikeluarkan itu merupakan milik orang lain yang berhak menerimanya. Pemelik harta hanya merupakan jembatan, perantaraan dan tempat penitipan sementara saja. Allah akan mengujinya, apakah ia rela memberikan hak orang lain dengan ikhlas atau tidak.

\section{METODE PELAKSANAAN}

Dalam Pengabdian ini metode yang digunakan dalam pelaksanaan adalah Meningkatkan efektivitas zakat dalam pengembangan ekonomi masyarakat di Kabupaten Deli Serdang. Meningkatkan keunggulan dan kelemahan system zakat dalam pengembangan ekonomi masyarakat Deli Serdang. Mengatasi kendala yang dihadapi dalam menerapkan system zakat dalam pengembangan ekonomi masyarakat Deli Serdang.

\section{HASIL \& PEMBAHASAN}

Segala kewajiban yang diberikan Allah kepada hambaNya pasti membawa kebaikan dan manfaat bagi manusia, baik di dunia maupun di akhirat. Demikian halnya dengan pelaksanaan zakat, bila dilaksanakan secara ikhlas akan membawa manfaat bagi manusia terutama sekali dalam bidang peningkatan perekonomian masyarakat, antara lain:

Pertama : Zakat bermanfaat mengembangkan harta benda dalam masyarakat. Konsep seperti ini telah ditegaskan Allah dalam firmanNya :"Ambillah dari harta mereka sedekah (zakat), dengan zakat itu dapat mensucikan dan mengembangkan harta mereka"(At Taubah 103).

Makna ayat di atas menunjukkan bahwa sesungguhnya pelaksanaan zakat itu merupakan upaya pembersihan dan pengembangan harta itu sendiri. Sebab di dalam harta yang dicari itu tercampur di dalamnya harta milik orang lain, seperti hak fakir, miskin, orang mu`allaf dan lain sebagainya.

Jadi zakat yang dikeluarkan itu pada hakekatnya bukan milik si pemberi zakat, melainkan milik orang lain yang dititipkan Allah kepadanya. Jika sesorang tidak mau mengeluarkan zakat, berarti ia rela hartanya tetap menjadi kotor karena masih bercampur dengan milik orang lain.

Kalau harta tetap dalam keadaan kotor, tentu ia sulit berkembang. Sebaliknya, jika harta telah stril dari kotoran dan penyakit, secara otomatis harta itu lebih mudah tumbuh dan berkembang secara baik. Oleh karenanya, harta itu harus dibersihkan dengan cara mengeluarkan zakat sekali dalam setahun bagi orang yang sudah memiliki kemampuan berzakat.

Sesungguhnya tidak ada orang yang mengalami kerugian dalam berzakat, justru sebaliknya malah keuntungan yang akan diperoleh secara berlipat ganda sebagaimana yang difirmankan Allah :" Dan apa yang kamu berikan berupa zakat yang kamu maksudkan 
untuk mencapai keridhoan Allah, maka yang berbuat demikian itulah orang-orang yang melipat gandakan pahalanya"(Ar Rum 39).

Ayat di atas menunjukkan bahwa orang yang mengeluarkan zakat secara ikhlas, sebenarnya ia akan memperoleh keuntungan di sisi Allah SWT. Bentuk keuntungan yang dimaksudkan di sini bermacammacam, seperti makin banyaknya orang yang suka padanya, makin berkembangnya usaha yang dilakukannya, munculnya kebahagiaan pada dirinya dan lain sebagainya.

Kedua : Zakat bermanfaat menumbuhkan sifat kasih sayang terhadap sesama manusia. Ibadah zakat selalu berhubungan dengan kaum lemah, sebab mereka adalah sasaran utama dalam pendistribusian zakat itu sendiri sebagaimana Allah berfirman :"Seungguhnya zakatzakat itu hanyalah untuk orang-orang fakir, orang-orang miskin, penguruspengurus zakat, para mu allaf yang dibujuk hatinya, untuk memerdekakan budak, orang-orang yang berhutang, untuk jalan Allah dan orang-orang yang sedang dalam perjalanan, sebagai suatu ketetapan yang diwajibkan Allah"(At Taubah 60).

Zakat merupakan jembatan yang menghubungkan antara si kaya dengan delapan kelompok kaum lemah sebagaimana diterangkan dalam ayat di atas. Artinya, disaat orang melaksanakan zakat, disaat itu pula ia teringat dan melihat sendiri betapa penderitaan yang dirasakan oleh kaum lemah tersebut, sehingga tumbuhlah sifat kasih sayangnya untuk selalu memberikan pertolongan kepada mereka.

Zakat merupakan buah kasih saying manusia sebagai makhluk sosial dan juga merupakan wujud implementasi ketaatan manusia sebagai hamba Allah. Melalui zakat ini sebenarnya telah ikut berperan dalam memperbaiki tatanan hubungan antara sesama manusia dan juga memperbaiki hubungan dengan Sang Pencipta.

Ketiga : Zakat bermanfaat menghilangkan rasa dengki antara si miskin dengan si kaya. Manusia pada umumnya selalu menyegani dan menghormati orang yang berbuat baik kepadanya. Demikian halnya dengan orang yang rajin berzakat, niscaya ia disenangi dan dihormati oleh masyarakat, khususnya mereka yang pernah menerima zakat darinya. Bukan itu saja, masyarakat yang tinggal di sekitarnya pun ikut aktif dalam menjaga dan memelihara hartanya dari gangguan orang lain.

Kedengkian dan iri hati dapat tumbuh akibat melihat seseorang yang berada dalam hidup berkecukupan tanpa mau mengulurkan bantuan kepada orang lain. Kedengkian hati itu berkembang menjadi permusuhan, di mana si miskin mencuri harta si kaya dan si kaya merasa resah dan terganggu ketenangannya sebagaimana diterangkan Allah SWT dalam firmanNya :"Jika Tuhan meminta harta bendamu (sebagai zakat dan sodakah) dan Dia mendesakmu agar engkau memberikan semuanya, niscaya kamu akan kikir, karenanya Dia hanya minta sebagian dan itupun kamu tetap kikir, maka Dia akan menampakkan kedengkian di antara kamu"(Muhammad 37).

Keterangan ayat di atas menunjukkan bahwa sikap enggan mengeluarkan zakat, akan menumbuhkan sifat kebencian dan permusuhan dalam masyarakat. Oleh 
karenanya, jika memang kedengkian dan kebencian tidak terjadi, hendaknya rajin mengeluarkan zakat sekali dalam setahun bagi orang yang berkemampuan.

Keempat : Zakat bermanfaat menumbuhkan sifat ikhlas. Melalui pelaksanaan ibadah zakat ini ternyata dapat menumbuhkan sifat ikhlas bagi pelakunya. Sebab orang yang mau melaksanakan zakat, secara pelanpelan jiwanya terbentuk menjadi pelapang, pengasih dan penuh perhatian terhadap sesama. Untuk sampai pada sifat ini memang tidak mudah, tetapi harus melalui proses dan latihan, di antaranya dengan jalan mengeluarkan zakat, infaq, shadaqah, dan lain sebagainya.

Yusuf Qardawi berpendapat bahwa setiap manusia memiliki benih-benih keikhlasan yang ada dalam hatinya. Namun benih itu harus dipupuk dan ditumbuh kembangkan melalui "pemberian" yang bermanfaat pada orang lain. Bagi siapa yang suka memberi berarti ia suka benih itu tumbuh dan berkembang.

Oleh karenanya setiap orang punya potensi untuk meraih predikat ikhlas dalam beramal, hanya saja pengembngannya diserahkan kepada individu masing-masing. Semakin sering orang mendermakan hartanya baik melalui zakat, shadaqah dan lainnya, berarti semakin tumbuh pula benih keikhlasan yang ada dalam dirinya.

Sifat ikhlas ini sangat penting bagi kehidupan manusia, karena ia merupakan ruhnya amal. Syekh Mustafa Gulayani berpendapat bahwa pekerjaan itu ibarat badan, sedangkan ruhnya adalah ikhlas. Dan setiap badan yang berpisah dengan ruh akan menjadi mati dan tentu tidak memiliki manfaat sama sekali.
Begitulah gambaran pekerjaan yang berpisah dengan nilai-nilai keikhlasan ('Jjatunnashihin, Jamurah, Pekalongan, 13).

Untuk menumbuhkan rasa keikhlasan dalam mengeluarkannya, perlu ditanamkan dalam diri masingmasing bahwa pada setiap harta yang dimiliki itu terdapat sebagian harta milik fakir miskin yang dititipkan Allah kepada pemiliknya. Kemudian diperintahkan oleh Allah SWT untuk disampaikan kepada orang yang berhak menerimanya. Oleh karenanya, zakat yang dikeluarkan itu sebenarnya bukan milik orang yang berzakat, melainkan milik orang lain yang dititipkan Allah kepadanya.

Jadi apalah beratnya memberikan harta kepada pemiliknya. Sebagai contoh, jika ada seseorang memberikan 5 goni beras kepada kita, kemudian orang tersebut menyuruh kita untuk memberikan satu goni kepada orang miskin. Tentu kita tidak merasa keberatan, karena masih ada sisa 4 goni lagi sebagai milik pribadi.

Kelima : Pelaksanaan ibadah zakat bermanfaat dalam menciptakan ketenangan dan ketentraman hidup dalam masyarakat. Orang yang gemar mengeluarkan zakat, hidupnya selalu dihiasi oleh kebahagiaan, kedamaian dan ketenteraman. Sebab banyak orang menyukainya akibat kebaikan yang ia lakukan berupa pengeluaran zakat secara rutin sekali dalam setahun. Orang yang suka berzakat, niscaya kawannya bertambah banyak, musuhnya semakin tidak ada.

Orang yang mengeluarkan zakat dengan penuh keikhlasan dan mengharap rido Allah SWT pasti hatinya menjadi senang dan bahagia, karena ia dapat menolong orang yang 
membutuhkan pertolongan. Dengan adanya ketenangan batin dari pemberi zakat, ia akan lebih mengkonsentrasikan usaha dan pemikirannya untuk pengembangan hartanya, di samping mendorong terciptanya daya beli baru dari penerima-penerima.

Selain suatu kewajiban, zakat juga merupakan salah satu perbuatan baik dari sekian banyak perbuatan baik yang dikenal dalam Islam. Setiap perbuatan baik yang dilakukan niscaya membawa kebahagian dalam kehidupan bermasyarakat sebagaimana yang difirmankan Allah :"Adapun orang yang beriman dan beramal shaleh, bagi mereka kebahagiaan dan tempat kembali yang baik"(Ar Rad 28).

Pengertian beramal shaleh sebagaimana yang disebutkan dalam ayat di atas adalah segala perbuatan yang diridhai Allah SWT, seperti perbuatan mengeluarkan zakat, bershadaqah, memelihara anak yatim dan lain sebagainya. Bentuk kebahagiaan yang diperoleh melalui perbuatan baik itu banyak, antara lain terciptanya rasa aman dan ketenteraman dalam diri pelakunya. Suasana Ketenteraman batin seseorang tentu akan mempengaruhi produktivitas dan kualitas pekerjaannya. Makin tinggi tingkat ketenangan dan kebahagiaan seseorang, maka makin tinggi pula produktivitas kerjanya.

Sudah merupakan fitrah bahwa manusia pada hakekatnya sangat menyukai kebaikan dan keindahan. Kebaikan itu merupakan kedamaian dan ketenteraman masyarakat. Buah perbuatan baik adalah kecenderungan seseorang untuk selalu berbuat baik kepada orang yang pernah berbuat baik kepadanya dengan penuh ketulusan dan keikhlasan dan inilah awal pintu rahmat sebagaimana yang difirmankan Allah:'Barang siapa yang mengerjakan amal shaleh, baik laki-laki maupun perempuan dalam keadaan beriman, maka sesungguhnya akan kami berikan kepadanya kehidupan yang baik dan sesungguhnya akan kami beri balasan kepada mereka dengan pahala yang lebih baik dari apa yang telah mereka kerjakan"(An Nahl 97).

Perlu diketahui bahwa mengeluarkan zakat merupakan kewajiban yang menyentuh langsung dengan kehidupan manusia secara umum. Berbeda dengan pelaksanaan kewajiban lainnya, seperti shalat atau zakat, jenis ibadah ini hanya berhubungan langsung antara hamba dengan Allah SWT. Andai saja ada orang yang tidak mendirikan shalat atau melaksanakan puasa, tidak begitu banyak pengaruhnya terhadap kehidupan masyarakat. Tetapi kalau kewajiban mengeluarkan zakat tidak dilaksanakan, secara otomatis akan mempengaruhi kondisi perekonomian, kestabilan dan ketentraman masyarakat, terutama bagi masyarakat miskin. Artinya jika zakat tersebut tidak dilaksanakan, maka akan banyak orang miskin yang tidak terbantu, seperti memberikan makannya, pakaiannya, usahanya dan lain sebagainya. Sebaliknya, jika zakat tesebut dilaksanakan secara rutin oleh pihak yang memiliki kemampuan, maka segala kebutuhan pokok kaum miskin akan terpenuhi secara baik. Oleh karenanya terbuktilah secara ilmiah bahwa pelaksanaan ibadah zakat benar-benar bernilai social yang apabila dilaksanakan akan banyak manfaatnya dalam membantu dan memberikan kebahagian bagi para kaum lemah. 
Keenam : Kewajiban menunaikan zakat hanya dibebankan kepada orang yang memiliki kemampuan saja, sedangkan bagi mereka yang belum memiliki kemampuan, maka tidak diwajibkan padanya membayar zakat. Jadi yang menjadi syarat diwajibkannya seseorang mengeluarkan zakat adalah jika ada kemampuan padanya.

\section{KESIMPULAN}

Ketatatan dalam menunaikan zakat memiliki manfaat besar bagi kehidupan manusia, terutama bagi orang yang berzakat dimana hartanya akan terus berkembang dan terus mendapat pahala, keberkahan dan rahmat dari Allah SWT. Zakat juga memiliki manfaat yang sangat besar untuk pengentasan kemiskinan di Indonesia, terutama kemiskinan di sekitar orang yang layak berzakat.

\section{REFERENSI}

Asrari Ibrahim dan Muchsin Ghozali, (1992), Cepat Tanggap Belajar Al Qur'an, Tulungagung, LP. Ma`arif NU.

A. Nawawi Ali, (2002), Pedoman Membaca Al Qur`an, Jakarta, Mutiara Sumber Widya.

Abdul Kadir Munsyi dan M. Nasai Hasyim, (1981), Pedoman Mengajar, Surabaya, Al Ikhlas.

Ali Imron, (1996), Belajar dan pembelajaran, Jakarta, Pustaka Jaya.

As`ad Humam, (1994), Cara Cepat Belajar Al Qur'an, Yogyakarta, Team Tadarus AMM.

Faisal, (1992), Format-format Penelitian Sosial, Jakarta, Rajawali Perss.

Gene L Wilkinson, (1984), Media dalam

Pembelajaran
Penelitian Selama 60 Tahun, Jakarta, CV. Rajawali.

Tian Belawati dkk, (2003), Pengembangan Bahan Ajar, Edisi Kesatu, Jakarta, Pusat Penerbitan Universitas Terbuka.

Tsaqifa, (2005), Cara Cepat dan Mudah Belajar Membaca Al Qur'an. Tersedia pada http://www.tsaqifa.org/saksi.ph p. Diakses pada tanggal, 19 Desember 2005.

Hendi Indyawan, Belajar Mudah Huruf Al Qur'an. Tersedia padahttp://www.ekuator.com/k talog.see.p?id=701. Diakses pada tanggal, 1 Juli 2006.

Harjanto, (1997), Perencanaan Pengajaran karangan, Jakarta, Rineka Cipta.

Muhammad Hasan Suaib, Belajar Al Qur'an Komputer. Tersedia pada

http://www.teknomediaweb.co m/alquran.htm. Diakses pada tanggal, 1 Juli 2006.

Mukhtar Yahya dan Fatchurrahman, (1993), Dasar-dasar Pembinaan Hukum Fiqh Islami, Cetakan Kesepuluh, Bandung, PT. Al Ma`arif.

Luluk Maslachah, 2006, Holy Qur`an Digital Book. Tersedia pada

http://lulukmaslachah.multiply. com/market/item/1. Diakses pada tanggal 1 Juli 2006.

Shahrin Awaludin, (2005), Kaedah Pengajaran Al Qur'an Masa Kini. Tersedia pada http://www.geocities.com/pend islam/quran.htm/. Diakses pada tanggal, 20 Desember 2005.

S.Nasution, (1982), Didaktik AsaAsas Mengajar, Bandung, Jemmars. 
Sukarno.Drs. N. Kertiasa. Hadiat.D. Padmawinata, Dasar-Dasar Yunus Hasan,Perbaikan Pendidikan Sains, Bhratara Karya Aksara,Jakarta,1981 \&Penyeragaman Bentuk Program Pendidikan dan Pelatihan (Program

W. James Popham. Eva L. Pengajaran),Pengawas Baker,Bagaimana Mengajar Secara Kanwil,Depdiknas Propinsi Sistematis, Kanisius, Yogyakart Riau, 1998-199 a,1981. 